\title{
The evaluation of sheltered workshops by employed personnel with disabilities
}

\section{Zakłady pracy chronionej w ocenie zatrudnionych w nich osób niepetnosprawnych}

\author{
Grażyna M. Czerwiak¹, Roman Trela² \\ ${ }^{1}$ Department of Nursing Skills and Labour Organization, Institute of Nursing and Midwifery, Faculty of Health Sciences, \\ Jan Kochanowski University, Kielce, Poland \\ Head of the Department: Prof. Bogdan Chazan MD, PhD \\ ${ }^{2}$ Regional Labour Inspectorate, Kielce, Poland
}

Key words: disability, job, sheltered workshops.

Słowa kluczowe: niepełnosprawność, praca, zakład pracy chronionej.

\begin{abstract}
Introduction: Disability is a complex concept with different dimensions associated with functional limitations of an individual and/or environment. From one point of view, scientific and technological progress increases the chances of being active in professional life, yet it requires high professional qualifications.

Aim of the research: The aim of the study was to investigate the employment character in those workshops. The theme of the research was the assumption that the process of rehabilitation of disabled persons is achieved in a complex social system. Material and methods: A diagnostic survey with the use of a customised questionnaire was carried out in November/December 2013 among 108 persons with disabilities employed in sheltered workshops in the Świętokrzyskie Province.

Results: The most common causes of disability among the respondents were the locomotor system, neurological, respiratory, and circulatory diseases. The obstacles in establishing interpersonal contacts would include the fear of negative feedback in their close environment, the lack of knowledge in society about disability, architectural barriers, and appearance. The disabled expected both economic and informative support.

Conclusions: The activity of persons with disabilities depends on employment opportunities in the labour market, but also on the candidate's education, age, and their degree of disability. The sheltered workshops reinforce the sense of economic security and social ties, whereas employment itself brings a particularly appreciated value for this population.
\end{abstract}

\section{Streszczenie}

Wprowadzenie: Niepełnosprawność jest pojęciem o zróżnicowanym wymiarze, związanym z ograniczeniami funkcjonalnymi jednostki i/lub środowiska. Z jednej strony postęp naukowo-techniczny zwiększa szansę aktywizacji zawodowej osób niepełnosprawnych ruchowo, zmienia się charakter zatrudnienia - z pracy fizycznej na intelektualną, a z drugiej praca umysłowa wymaga wysokich kwalifikacji zawodowych.

Cel pracy: Celem badań było poznanie specyfiki zatrudnienia w zakładach pracy chronionej. Motywem badawczym było założenie, że proces rehabilitacji osoby niepełnosprawnej dokonuje się w złożonym systemie społecznym.

Materiał i metody: Sondaż diagnostyczny z wykorzystaniem ankiety własnej przeprowadzono w listopadzie i grudniu $2013 \mathrm{r}$. wśród 108 osób niepełnosprawnych zatrudnionych w zakładach pracy chronionej województwa świętokrzyskiego.

Wyniki: Najczęstszą przyczyną niepełnosprawności wśród badanych były choroby narządu ruchu, następnie choroby neurologiczne, układu oddechowego i krążenia. Przeszkodą w nawiązywaniu kontaktów interpersonalnych był lęk przed negatywną postawą otoczenia, deficyt wiedzy o niepełnosprawności, bariery architektoniczne, wygląd zewnętrzny. Niepełnosprawni oczekiwali wsparcia ekonomicznego i informacyjnego.

Wnioski: Aktywność zawodowa osób niepełnosprawnych zależy nie tylko od oferty zatrudnienia na rynku pracy, lecz także od wykształcenia, wieku kandydata i stopnia jego niepełnosprawności. Zakłady pracy chronionej wzmacniają poczucie bezpieczeństwa ekonomicznego i więzi społecznych, natomiast praca jest szczególnie cenioną wartością w tej populacji.

\section{Introduction}

The scale of disability in Poland and worldwide enforces taking up actions in order to improve the living conditions of this population. Disability is a com- plex concept associated with functional limitations of the individual and/or their environment.

According to Grossman, there are more than 500 million people with disabilities in the world, including $11 \%$ under the age of 30 years. This means 
that almost every tenth person is disabled. In Europe, the crucial factor is the 20-year increase in life expectancy since 1925 [1].

The purpose of social policy of the state is the opportunity for equality and integration of people with disabilities. Apart from fighting against discrimination, the prevention of social exclusion is an important area. For people with disabilities, professional work is of particular importance because it is the next stage of rehabilitation, which provides self-esteem, helps to improve the economic status, and compensates for social contacts and/or limitations resulting from disability [2].

The professional activity of people with disabilities depends on the current employment opportunities in the labour market, the age and education of the candidate, but also on their degree of disability. One of the barriers for the employment of disabled people is the employers' perception of lower work efficiency of these people and the costs of workplace adjustments.

According to Ochonczenko, we can observe a contradiction between expectations and capabilities of a disabled person, as well as between the requirements and expectations of employers. Changes in attitude and regulations promoting employment are essential [3].

In Poland, there is a predominance of inactive people, who constitute about $80 \%$ of this population. The main causes of disability in Poland are: illnesses (80\%), injuries (14\%), and birth defects (5\%). The most common diseases that cause disability are those of the circulatory and the locomotor system. The vast majority of disabled people are in the productive age and over 60 years of age [4].

The situation of disabled people in the labour markets of the European Union is diverse. In recent years, we can observe their integration (in the family, at school, and in the workplace) with non-disabled people, which has an impact on their quality of life [5].

In Poland, in accordance with the Act dated August 27, 1997 on Vocational and Social Rehabilitation and Employment of Disabled Persons, "disability means a permanent or temporary inability to fulfil social roles because of permanent or long-term impairment of the body efficiency, in particular resulting in the inability to work". The Act refers to those whose disability has been confirmed by the judgment:

- "a significant degree of disability includes a person with an impairment of body efficiency, unable to work or able to work only in sheltered work conditions, and requiring permanent or long-term care and the assistance of others,

- a moderate degree of disability includes a person with an impairment of body efficiency, unable to work or able to work only in sheltered work conditions, or requiring temporary or partial assistance of others,
- a slight degree of disability includes a person with an impairment of body efficiency resulting in reduced ability to work compared with another person having similar professional qualifications and full efficiency [6].

Apart from the statement of a degree of disability (significant, moderate, slight), the judgment includes indications concerning inter alia: employment concerning psychophysical capabilities of a person, forms of rehabilitation, supply of orthopaedic equipment, and proposals for vocational training.

The entities working for people with disabilities in the area of integration at the central level in Poland are the Government Plenipotentiary for Persons with Disabilities and the State Fund for Rehabilitation of Disabled Persons (PFRON).

Frequent changes in legislation that may give rise to concerns in society, indicating a lack of effective strategy. Non-government organisations created by the individuals themselves as well as volunteers represent an alternative. Their work is financially supported by the state and, increasingly, by private persons. The latter is promoted by the decision of the Ministry of Finance of 2004 that guarantees the possibility to deduct $1 \%$ of income tax on the accounts of public benefit organisations [6].

An assessment of psychophysical capabilities of people with disabilities in the context of professional activation should do the following:

- facilitate the choice of vocational education, work position, or professional activities of people with disabilities,

- enable vocational and social rehabilitation,

- protect against the development of dysfunctions [7].

According to Frackiewicz "Limited initial and periodic examinations prevent the rational management of human capital, resulting in irreversible health effects" [8].

The actual risks associated with hiring people with disabilities in the open labour market appeared in the context of these findings. This raises further questions as to whether and how the integration principle of disabled with non-disabled will be implemented in the workplace.

From one point of view, scientific and technological progress increases the activation of people with physical disabilities. The nature of employment changes from physical to intellectual work; however, the latter form requires high professional qualifications.

Due to mass development of information technology we can observe the rise of new forms of employment, such as telework, addressed also to disabled people with reduced mobility.

In the opinion of Frackiewicz and Koczur, teleworking has contributed to flexible working hours and reduced the necessity to transport a worker to a workplace. Such organisation of work time allows 
people with disabilities to implement recommendations concerning rehabilitation and therapy. The model of telework means the employer can assess employees on the basis of performance, not on their presence in a company or physical appearance [9].

According to Apolinarska, there may be different organisational forms of telework, such as home, alternate, and mobile telework. Home telework is the oldest form of employment of people with disabilities in Germany [10].

The implementation of the telework model does not necessarily mean changes of the current organisational system in a company. According to the telework concept assumptions, this kind of work can refer to a group of employees, such as IT specialists, consultants, or departments, for instance administration or marketing.

As well as advantages, there are also disadvantages to this form of employment. Teleworking is conducive to social isolation and/or excessive working time. In addition, insufficient access to Internet services in rural areas and educational barriers may limit the development of positions based on high professional qualifications.

\section{Aim of the research}

The aim of the research was to investigate the employment character in those workshops. The theme of the research was the assumption that the process of rehabilitation of disabled persons is achieved in a complex social system.

The choice of issues was associated with the many years of experience of the authors, resulting from close contact with people with disabilities. Contact with complex health and existential problems arising from disability was the inspiration for the authors to carry out the research.

\section{Material and methods}

A diagnostic survey with the use of a customised questionnaire was carried out in November/December

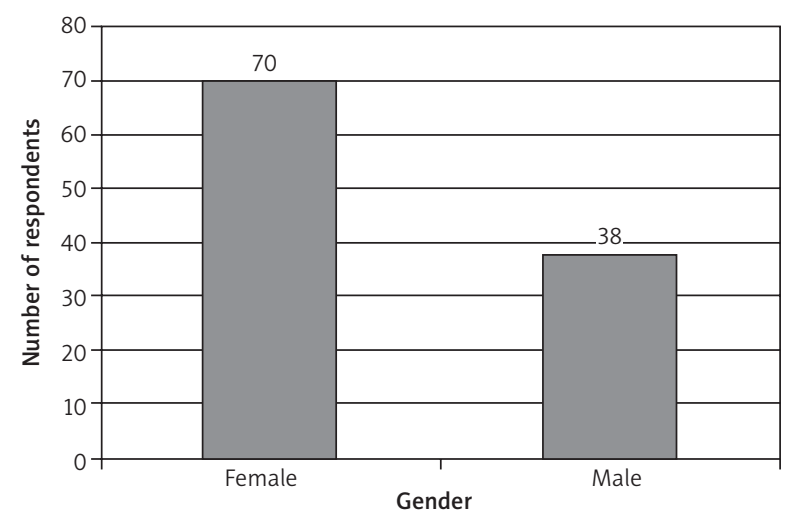

Figure 1. Respondent groups by gender
2013 among 108 persons with disabilities employed in sheltered workshops (multiple companies chosen randomly in: Kielce, Starachowice, Skarżysko-Kamienna, and Kałków in the Świętokrzyskie Province).

Participation in the research was voluntary and anonymous and all respondents had a valid certificate of disability. The classification of causes of disability included in the research was based on data present in the Decree of the Minister of Labour and Social Policy dated July 15, 2003 concerning the judgment of disability and the degree of disability - Dz.U. (Journal of Laws) No. 139; Item 1328 as amended [11].

\section{Results}

The results of the study were presented in Figures $1-11$.

\section{Discussion}

The terminology concerning disability has been changing throughout the development of rehabilitation. Contemporary integration trends contribute to the evolution of disability towards the so-called social model. Communities of people with disabilities participate more and more actively in self-help groups, and government and non-government organisations.

People with disabilities usually do not lose the ability to perform diverse kinds of work due to health problems. They retain those skills, which can lead to prospective employment.

According to Prałat, professional activation plays special role in social rehabilitation. A person who is fulfilled in a professional life obtains confidence in everyday activities, naturally establishes interpersonal relationships, and "gets rid of the feeling of being a burden to others" [12].

Success in vocational rehabilitation is achieved when a disabled person is satisfied with the fact of their employment and, in the opinion of their supervisor, meets the requirements for their entrusted

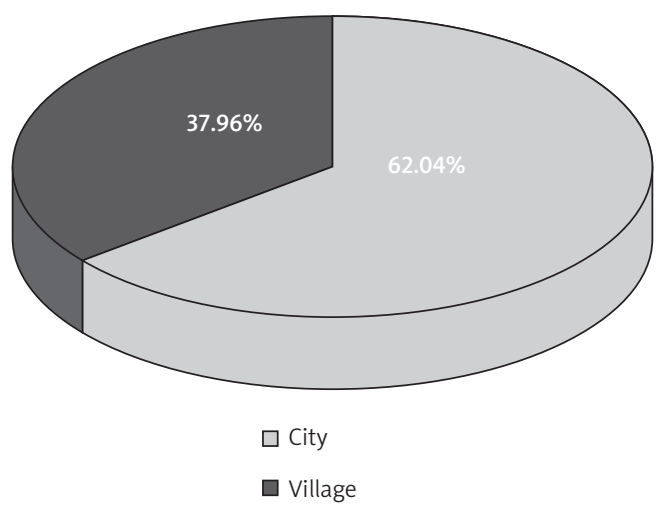

Figure 2. Place of residence of the respondents 


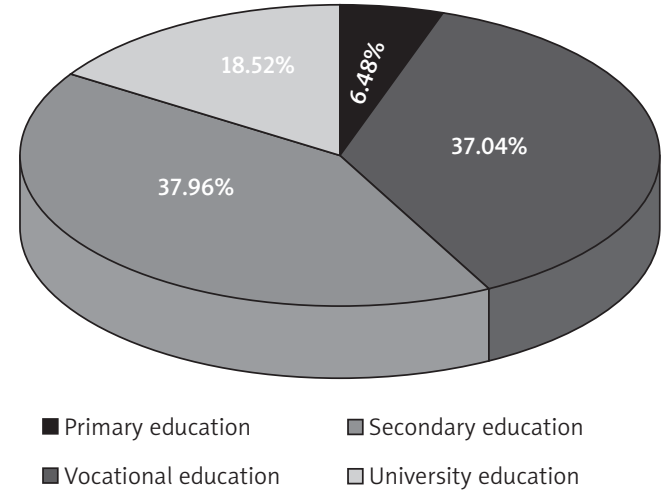

Figure 3. Employed in a sheltered workshop by education

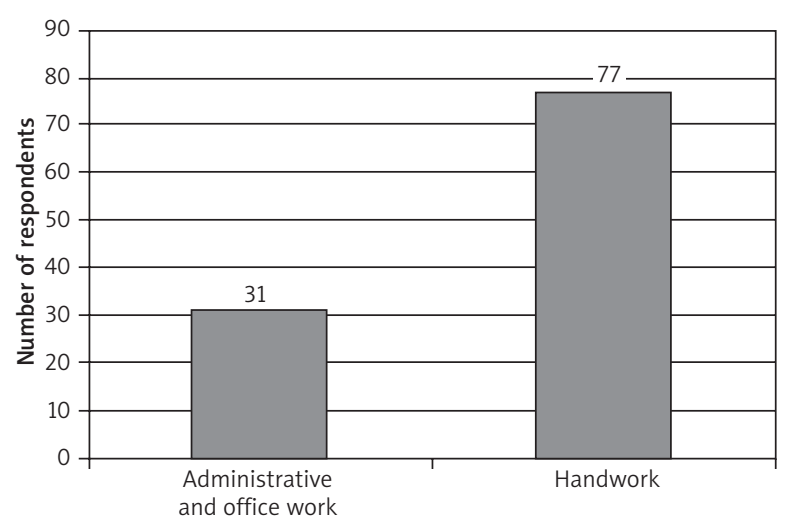

Figure 4. The type of work

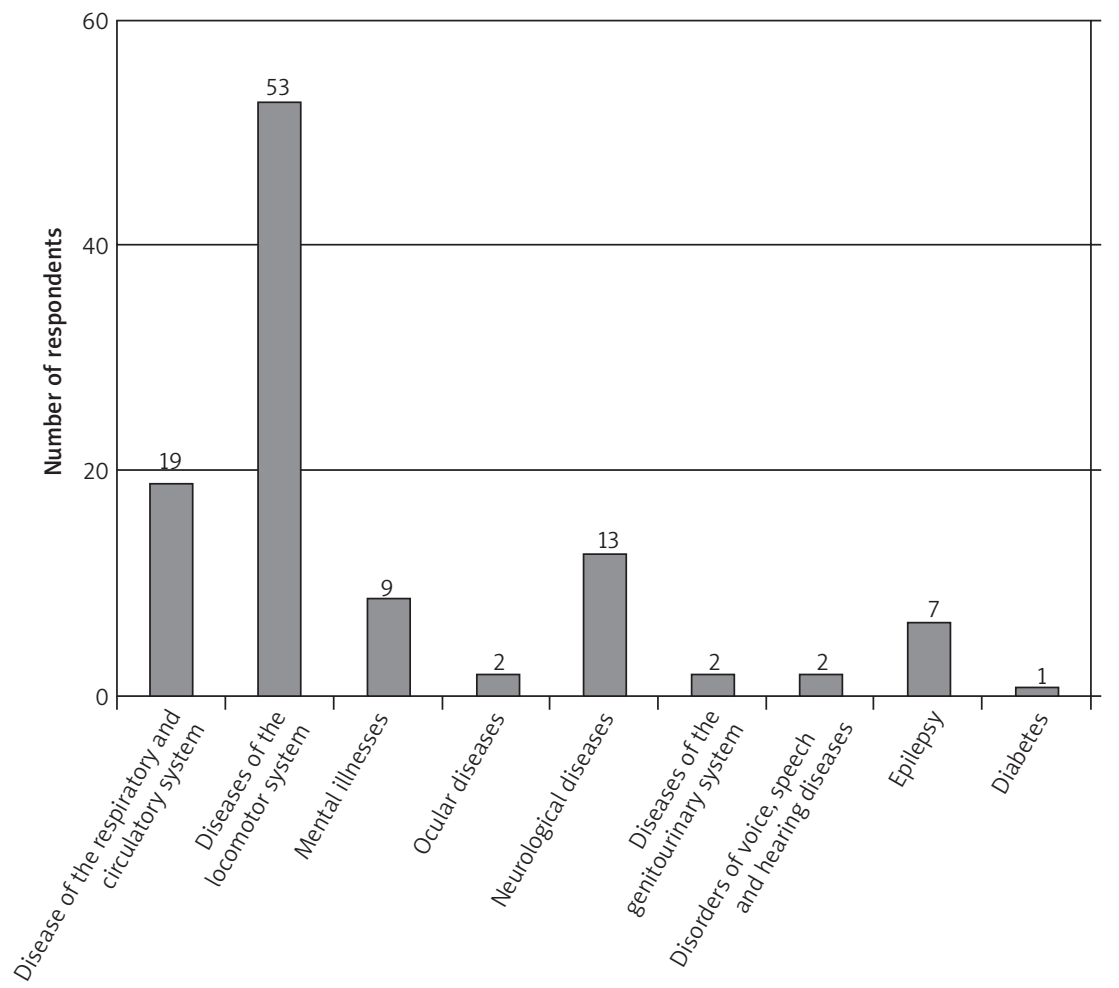

Figure 5. Causes of vested disability among respondents

scope of activities. "A man/woman well adapted to work - as shown by research - is still an active person, who has strong motivation and takes actions more often than others, despite functional limitations and problems" [13].

In this context, in our research, the majority of working people with disabilities assessed current working conditions as good or very good (Figure 6). We observed respondents' satisfaction arising from employment, often being a culmination of their research in the labour market.

A matter which requires an urgent solution is safety in the work environment. This population is subject to a higher risk of occupational accidents. For many employers, this poses a sufficient reason to refrain from employment and/or difficulty in developing an objective occupational risk.

According to Stochmiałek, the most important factor that ensures the process of making a disabled person grow better is social support. This comprises an environmental force that counteracts consequences resulting from unpleasant restrictions [14].

Based on the results of this research, it was found that the most often indicated obstacles in establishing interpersonal contacts were the fear of negative feedback from the community, a deficit of knowledge in 


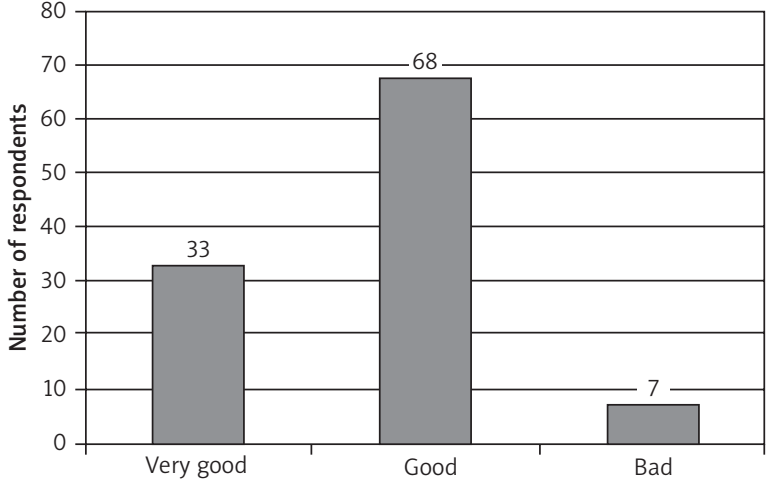

Figure 6. Evaluation of working conditions in the sheltered workshop - the opinions of respondents

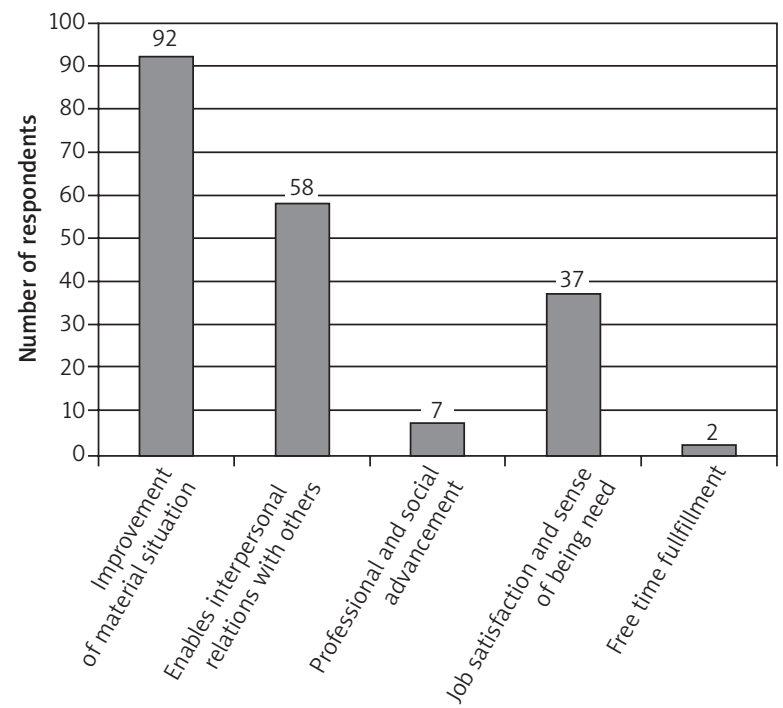

Figure 7. Motivation for employment and its importance according to respondents

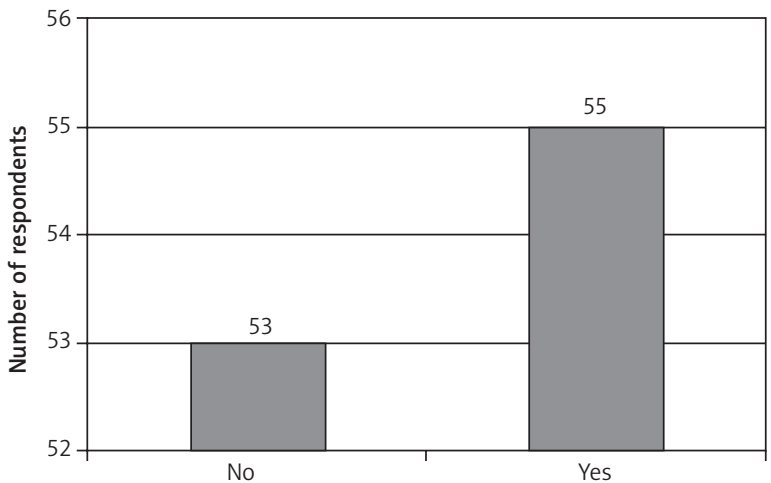

Figure 8. The need for medication during the working day society concerning disability, architectural barriers, and appearance (Figure 10).

Therefore, mental barriers can be still observed both by disabled people and by employers. With relation to the people with disabilities those are continually low education and lack of faith in their own abilities; whereas the employers are mainly impeded by the formalised system of subsidies, architectural and communication barriers, fear of work productivity, and stereotypical opinions about their company's prestige.

Another important aspect conducive to their professional activation is the promotion of knowledge about disability in society. It is necessary to develop medical and rehabilitation services in rural areas and small towns.

The success of vocational rehabilitation of this social group depends on many factors. The initial stage of rehabilitation of people with disabilities is connected with the health care system and support from the people closest to them, i.e. their family. Sheltered workshops increase employment opportunities for people with a judgment of significant and moderate disability degree.

The integration process must occur at the local level because in a natural environment existential problems constitute an everyday reality. Associations of people with disabilities and organisations working for them bring opportunities for improvement. As noted in the Madrid Declaration, "without the involvement of the whole of society, including the participation of disabled people in the struggle to ensure their rights, legislation remains a dud cheque" [15].

Vocational rehabilitation of people with disabilities begins in occupational therapy workshops, through vocational activity workshops, and in sheltered workshops, leading to employment in the open labour market. Due to the social adaptation of a disabled person, such employment is the most desirable [8].

Our findings indicate that people with disabilities employed in sheltered workshops expect, first of all, economic and information support and help solving their existential problems. This was followed by caring, medical services, and psychological support (Figure 11).

The authors of the World Labour Report emphasise that "work is a central factor for the quality of life of an individual". It is not only important because of the salary but for optimal development of the individual, a sense of social identity, and social integration [16].

Analysing the areas of quality of life of people with disabilities, Brookings and Bolton do not omit employment and the social functioning of an individual. According to the authors, professional work is an important contribution to the process of self-realisation and the sense of quality of life. Professional work gives meaning to life as well as is the source of life satisfaction of the respondent [17]. 


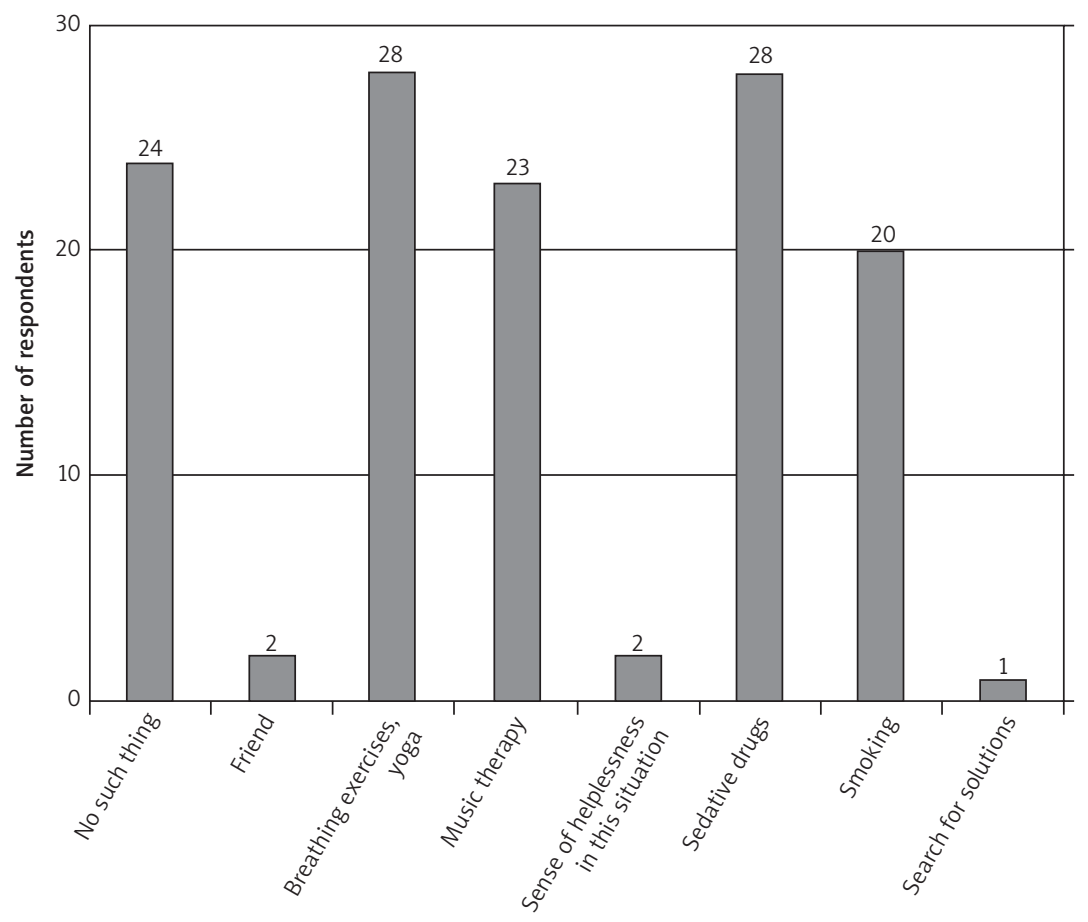

Figure 9. The means of coping with stress in the studied group

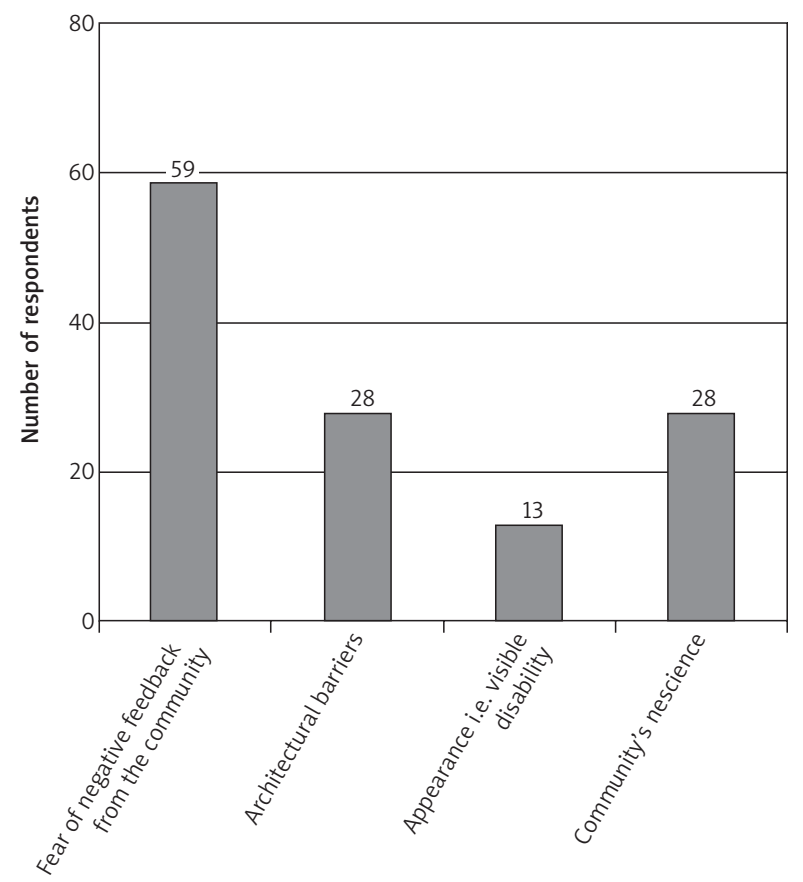

Figure 10. The obstacles in interpersonal contacts for people with disabilities

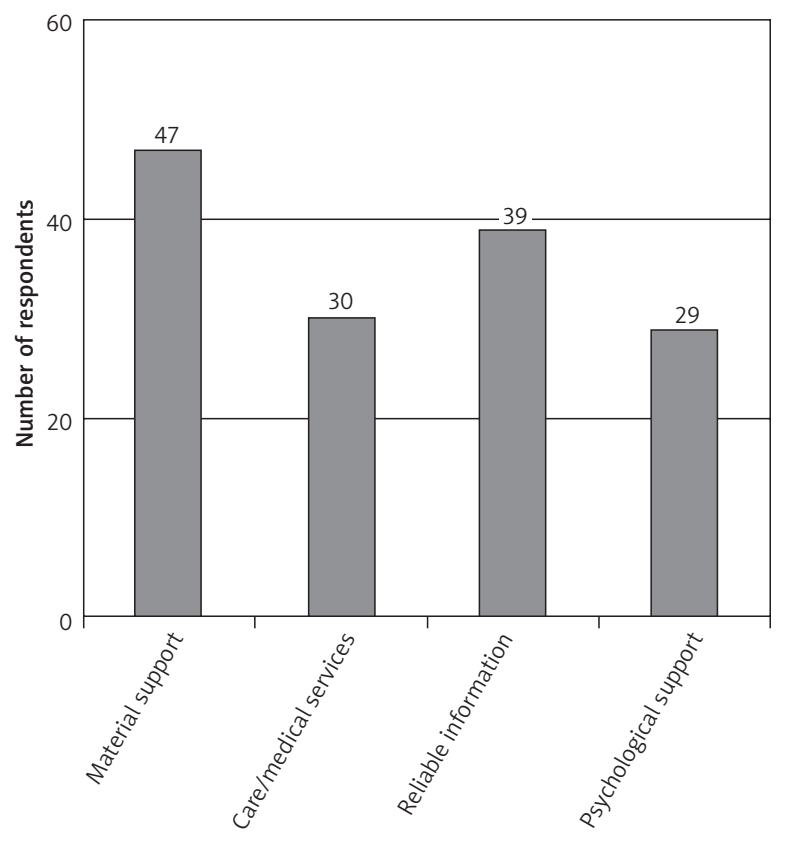

Figure 11. The type of support expected by people with disabilities 
Usually, the rate of disabled people in society is determined by age. The increase in disability (especially in Poland and Finland) affects people over 45 years of age. In Poland the percentage of people who experience long-term health problems is high among older people and low among young people. In all EU countries the share of people with disabilities among the unemployed is higher than the share of people with disabilities among the employed. This fact confirms once again the worse situation of people with disabilities in the labour market [18].

Our findings relate to a particular part of disabled persons' lives, and it is unlikely to predict individual successes or failures in their development. At this stage of the research, it should be noted that previous experience of disability in the group of respondents increased their determination and aspirations, including the search for meaning in their life. Such objectives are confirmed by the examinations performed by Kamusińska and Czyż. Persons with physical disabilities and their families should receive necessary support [19]. According to Polit et al., the largest percentage in the examined population with rehabilitation prescribed within the ZUS (Social Insurance Institution) prevention of disability were persons with lumbar spinal pain syndromes [20].

Comparing the situation of people with disabilities across the EU is extremely difficult because of the lack of a uniform definition of disability, as well as the cultural diversity of the member states. In Poland the most numerous group of unemployed people with disabilities consists of people in the age range 45 to 54 years. A disadvantage of unemployment among job seekers is an increase in the share of long-term unemployed, i.e. people being out of work for more than 12 months. In the second half of 2013 in the Świętokrzyskie Province 48 sheltered workshops were operating. In Poland, the largest employment in those workshops was recorded in the Dolnoślaskie Province - 23,656 people, in the Mazowieckie Province - 23,584 people and in the Wielkopolskie Province - 20,552 people; and the smallest in the Opolskie Province - 2637 people and Lubelskie Province - 2887 people [21].

Polish accession to the European Union made it possible to obtain funds inter alia for implementation of initiatives for people with disabilities and their families. International exchange of experience in creating standards in the areas of health protection, education, and employment should help to improve the quality of life of this social group.

\section{Conclusions}

Based on the results of this research, it was found that: the most common causes of disability in the group of respondents were diseases of the locomotor system, which caused pain in joints and/or spine. Neurological, respiratory, and circulatory system dis- eases where also recorded as further items. The vast majority of working people with disabilities assessed their current working conditions as good or very good. The most commonly indicated obstacle in interpersonal relations was the fear of negative feedback from the community, followed closely by the lack of knowledge about disability, architectural barriers, and appearance. In stressful situations, most respondents received sedatives and performed breathing exercises and/or yoga. The feeling of loneliness among respondents indicates that in the category of "friend", "trying to find solutions" there were single responses given. Disabled persons employed in sheltered workshops expect economic and information support. Medical care services and psychological support were recorded as being subsequent in importance on the list.

\section{Conflict of interest}

The authors declare no conflict of interest.

\section{References}

1. Fizjoterapia XXI wieku. Grossman J (ed.). Olsztyńska Szkoła Wyższa, Olsztyn 2004; 46-9.

2. Szczupał B. Sytuacja zawodowa osób niepełnosprawnych. In: Pedagogika specjalna - kontynuacja tradycji dla przyszłości. Zabłocki K, Gorajewska D (eds). APS, Warsaw 2004; 76-92.

3. Ochonczenko H. Sytuacja na rynku pracy osób niepełnosprawnych w dobie zmian społecznych i gospodarczych w Polsce. In: Człowiek niepełnosprawny w różnych fazach życia. Bąbka J (ed.). Wydawnictwo Akademickie Żak, Warsaw 2004; 225-30.

4. Czernicki J. Wybrane zagadnienia demograficzne i epidemiologiczne rehabilitacji medycznej. Urban \& Partner, Wroclaw 2003; 179.

5. Speck O. Niepełnosprawni w społeczeństwie. Gdańskie Wydawnictwo Psychologiczne, Gdansk 2005; 200-14, 381-8.

6. Ustawa z dnia 27 sierpnia 1997r o rehabilitacji zawodowej i społecznej oraz zatrudnianiu osób niepełnosprawnych. Dz. U. nr 123 poz. 776 z późn. zm.

7. Kurkus-Rozowska B. Ocena możliwości psychofizycznych osób niepełnosprawnych mogacych podjać pracę zawodową. KUP, Warsaw 1998; 4-9.

8. Frąckiewicz L, Koczur. Niepełnosprawni a praca. Wydawnictwo Akademii Ekonomicznej, Katowice 2004; 26-55.

9. Postawy wobec niepełnosprawności. Frąckiewicz L (ed.). Wydawnictwo Akademii Ekonomicznej, Katowice 2009; 16-29.

10.Apolinarska M. Telepraca - nowa szansa promocji osób niepełnosprawnych na rynku pracy. Niepełnosprawność i Rehabilitacja, Warsaw 2002; 2: 34-42.

11. Rozporządzenie MPiPS z dnia 15.07.2003 r. w sprawie orzekania o niepełnosprawności i stopniu niepełnosprawności - Dz. U. Nr 139 poz. 1328 z późn. zm.

12. Prałat K. Realizacja polityki państwa wobec osób niepełnosprawnych w związku z przystąpieniem Polski do Unii Europejskiej. Auxililum sociale. Wsparcie Społeczne 2003; 2: 134-9. 
13. Labor market in the era of globalization. Grodzicki JP (ed.). Polish-American Center for resolution of Labor Management Disputes Chicago, Gdansk 2009; 25-33.

14.Stochmialek J. Społeczna integracja dorosłych osób niepełnosprawnych. In: Integracja społeczna osób niepełnosprawnych. Dryżałowska G, Żuraw H (eds.). Wydawnictwo Akademickie Żak, Warsaw 2004; 158-67.

15. Człowiek niepełnosprawny rodzina i praca. Kościelska M, Aouil B (eds.). Wydawnictwo Akademii Bydgoskiej, Bydgoszcz 2004; 203-6.

16. Brown I, Brown RI. Quality of life and disability. Jessica Kingsley Publishers London and New York 2003; 122-44.

17. Brookings JB, Bolton B. Dimensions of satisfactoriness for works with severe handicaps to employment. Rehabil Psychol 1991: 21-30.

18. Van Oorschot W, Balvers M, Schols M, et al. European comparative data on the situation of disabled people: an annotated review. ANED, March 2012.

19. Kamusińska M, Czyż M. Influence of mobility impairment on family functioning. Studia Medyczne 2013; 29: 73-82.

20.Polit Ł, Strączyński M, Śliwiński Z. The most common reasons for medical referrals to the rehabilitation of the motion organ within the prevention of disability pension of social insurance institution. Studia Medyczne 2013; 29: 51-6.

21.Sytuacja osób niepełnosprawnych na rynku pracy w woj. Świętokrzyskim. Wydział Badań i Analiz Rynku Pracy WUP w Kielcach, Kielce 2013.

\section{Address for correspondence:}

Grażyna M. Czerwiak MD, PhD

Department of Nursing Skills and Labour Organization

Institute of Nursing and Midwifery

Faculty of Health Sciences

Jan Kochanowski University

Al. IX Wieków Kielc 19, 25-317 Kielce, Poland

Phone: +48 4136678 42, 509279582

E-mail: gczerwiak@o2.pl 